\title{
Władze Uniwersytetu Papieskiego Jana Pawła II w Krakowie
}

Naucza Sobór Watykański II: „Również troskliwą opieką Kościół otacza szkoły wyższe, zwłaszcza uniwersytety i fakultety"1. Wyrazem tej troski o uniwersytety kościelne jest także konstytucja apostolska o uniwersytetach i wydziałach kościelnych ${ }^{2}$. Konstytucja ta reguluje sprawy związane z istnieniem i działaniem uniwersytetów kościelnych. Do tej kategorii uczelni należy Uniwersytet Papieski Jana Pawła II w Krakowie [dalej: UPJPII]. Dlatego normy jego statutu oparte są na postanowieniach przywołanej konstytucji: „Uniwersytet Papieski Jana Pawła II w Krakowie jest uczelnią kościelną, której charakter i działalność określa konstytucja apostolska Sapientia christiana ${ }^{3}$. W oparciu o postanowienia tej konstytucji statut UPJPII reguluje powołanie i działalność sprawujących władzę w Uniwersytecie Papieskim.

\section{Zwierzchnie władze Uniwersytetu}

W wielowiekowej kulturotwórczej działalności Kościoła katolickiego pojawiła się w XX wieku potrzeba ustanowienia i prowadzenia uniwersytetów kościelnych oraz uniwersytetów katolickich. Uniwersytety katolickie w swej działalności są inspirowane powszechną i publiczną obecnością idei chrześcijańskich, kościelne zaś inspirują się w swoich badaniach Objawieniem Bożym ${ }^{4}$. To rozróżnienie nie było jeszcze

\footnotetext{
${ }^{1}$ Deklaracja soborowa Gravissimum educationis [dalej: DWCh], 10.

2 Jan Paweł II, konst. apost. Sapientia christiana (15 kwietnia 1979), AAS 71 (1979), s. 469-499, thum. [w:] Posoborowe prawodawstwo kościelne, red. E. Sztafrowski [dalej: PPK], t. 12, z. 1, s. 210-256.

${ }^{3}$ Statut Uniwersytetu Papieskiego Jana Pawła II w Krakowie (5 lutego 2010) [dalej: Statut], 2.

${ }^{4}$ Por. S. Pasternak, Reorganizacja studiów kościelnych, szczególnie wykładów prawa kanonicznego, w świetle ,, Sapientia christiana”, „Prawo Kanoniczne” 23 (1980), nr 3-4, s. 218.
} 
obecne w Kodeksie prawa kanonicznego [dalej: KPK] z 1917 roku, który podaje normy odnoszące się do wszystkich uniwersytetów katolickich, bez względu na to, czy zajmowały się tylko naukami teologicznymi, czy też równocześnie świeckimi. Odrębne normy dotyczące nauk teologicznych wykładanych na uniwersytetach i fakultetach kościelnych podaje konstytucja apostolska Deus scientiarum Dominus ${ }^{5}$, która przyczyniła się do odnowy wyższych studiów kościelnych ${ }^{6}$. Rozróżnienie na uniwersytety katolickie i kościelne podtrzymuje i rozwija KPK z 1983 roku oraz dwie konstytucje apostolskie: Sapientia christiana i Ex corde Ecclesiae autorstwa Jana Pawła II. Warto dodać, że obydwie formy uczelni wyższych oprócz różnic posiadają również elementy wspólne, które są regulowane analogicznymi normami ${ }^{7}$. W zależności od formy uczelni kształtuje się sprawowana w nich władza.

Uniwersytet Papieski Jana Pawła II w Krakowie należy do kategorii uczelni kościelnych. Jego najwyższą władzę stanowi papież, który nie sprawuje jej bezpośrednio, chociaż Uniwersytet Papieski w Krakowie został erygowany przez papieża Benedykta XVI. W dekrecie erygującym UPJPII napisano:

papież Benedykt XVI, dla uczczenia pamięci swojego znakomitego poprzednika Sługi Bożego Jana Pawła II postanowił Papieską Akademię Teologiczną w Krakowie podnieść do godności Uniwersytetu Papieskiego Jana Pawła II dla rozwijania nauk kościelnych ${ }^{8}$.

Papież swoją władzę wobec Uniwersytetu sprawuje przez Kongregację Edukacji Katolickiej. Obecnie po reformie dokonanej poprzez motu proprio Benedykta XVI Ministrorum institutio z dnia 16 stycznia 2013 roku nosi ona nazwę: Congregatio de Institutione Catholica (de Studiorum Institutis)9.

Kongregacja Edukacji Katolickiej, w imieniu papieża, sprawuje realną władzę, aczkolwiek niebezpośrednią, nad UPJPII. Wyraża się to najpierw w zatwierdzaniu statutu Uniwersytetu. Aktualny, pierwszy statut UPJPII został zatwierdzony dnia 5 lutego 2010 roku na okres pięciu lat ${ }^{10}$. Jest zwyczajem Kongregacji, że pierwsze zatwierdzenie statutu jest na okres pięciu lat, ad experimentum. Następnie zatwierdza ona wybór rektora, dziekanów wydziałów i dyrektora Instytutu Prawa Kanonicznego ${ }^{11}$. Wydaje nihil obstat przed nadaniem tytułu profesora oraz stanowisk

\footnotetext{
${ }^{5}$ Pius XI, enc. Quadragesimo Anno, (24 maja 1931), AAS 23 (1931), s. 241.

${ }^{6}$ Por. F. Bączkowicz, Prawo kanoniczne, t. 2, przygotowali do druku i uzupełnili J. Baron i W. Stawinoga, Opole 1958, s. 504n.

${ }^{7}$ Szerzej na ten temat por. J. Dyduch, Rola uczelni kościelnych i katolickich w świetle powszechnego prawodawstwa posoborowego, „Analecta Cracoviensia” 24 (1992), s. 135-151.

${ }^{8}$ Dekret Kongregacji Edukacji Katolickiej (19 czerwca) 2009, N. 1344/2005, Archiwum UPJPII.

9 "Communicatione” 45 (2013) nr 1, s. 12, art. 1.

${ }^{10}$ Kongregacja Edukacji Katolickiej, dekret N. 641/81, 5 lutego 2010, Archiwum UPJPII.

${ }^{11}$ Statut, n. 28, 2; n. 43; n. 176.
} 
profesora zwyczajnego i nadzwyczajnego ${ }^{12}$. Kongregacja zatwierdza także umowy o współpracy naukowej, jakie Wydział Teologiczny UPJPII zawiera z wyższymi seminariami duchownymi i innymi instytucjami teologicznymi, a także z wyższymi instytutami wiedzy religijnej ${ }^{13}$.

Pewne uprawnienia wobec uczelni kościelnych posiadają krajowe konferencje biskupie. KPK postanawia: „Konferencje biskupie oraz zainteresowani biskupi mają obowiązek i prawo czuwać nad tym, by na katolickich uniwersytetach wiernie były przestrzegane zasady doktryny katolickiej” (kan. 810). Chociaż norma przywołanego kanonu dotyczy bezpośrednio uniwersytetów katolickich, to jednak zgodnie z kan. 818, który postanawia, iż kan. 810 ma także zastosowanie do uczelni kościelnych, odnosi się w całej rozciągłości do uniwersytetów kościelnych. Zgodnie z zarządzeniami wykonawczymi do konstytucji Sapientia christiana Kongregacja zasięga opinii konferencji biskupich przed erygowaniem uniwersytetu czy fakultetu ${ }^{14}$.

W przypadku erygowania UPJPII Konferencja Episkopatu Polski na 345. Zebraniu Plenarnym w Białymstoku w dniach 26-28 września 2008 roku wyraziła następującą opinię:

biorąc pod uwagę wysoką jakość pracy naukowej prowadzonej przez Papieską Akademię Teologiczną w Krakowie, biskupi polscy jednogłośnie wyrazili poparcie dla nowo utworzonego Wydziału Nauk Społecznych, jak również erygowania Papieskiego Uniwersytetu Jana Pawła II w Krakowie ${ }^{15}$.

Konferencja Episkopatu Polski sprawuje pieczę nad uczelniami kościelnymi poprzez Radę Naukową Episkopatu Polski ${ }^{16}$. W przeszłości zajmowały się tym: Komisja ds. Nauki Katolickiej i Rada Naukowa Episkopatu Polski. Obie te struktury powstały z inspiracji i inicjatywy kard. Karola Wojtyły i odegrały kluczową rolę w walce o wolność nauki katolickiej w naszej ojczyźnie, walce, która toczyła się podczas prześladowań Kościoła i prób zawłaszczenia uczelni katolickich i kościelnych przez reżim komunistyczny w Polsce ${ }^{17}$.

Wymienione wyżej osoby fizyczne czy prawne, sprawujące na UPJPII władzę zwierzchnią, zasadniczo wykonują ją pośrednio, chociaż papieżowi przysługuje ona bezpośrednio. Inne osoby czy kolegia sprawują władzę w Uniwersytecie bezpośrednio:

${ }^{12}$ Tamże, n. 12, 10; n. 58; n. 59.

${ }^{13}$ Tamże, n. 20, 11; n. 137.

${ }^{14}$ Kongregacja Edukacji Katolickiej, Zarządzenie wykonawcze do konstytucji apostolskiej Sapientia christiana [dalej: Ordinationes], AAS 71 (1979), s. 500-521; thum. PPK, t. 12, z. 1, art. 45, § 2.

${ }^{15}$ Pismo Konferencji Episkopatu Polski (27 września 2008), Archiwum Kurii Metropolitalnej w Krakowie [dalej: AKMK].

${ }^{16}$ Akta Konferencji Episkopatu Polski, 9 (2004), nr 1, s. 113.

${ }^{17}$ Szerzej na ten temat, por. J. Dyduch, Kardynat Karol Wojtyła w stużbie Konferencji Episkopatu Polski, Kraków 2007, s. 93-125. 
W stosunku do całego Uniwersytetu władzę - ze swoimi kompetencjami - posiadają: wielki kanclerz, rektor, senat Uczelni, a w stosunku do poszczególnych wydziałów: dziekan i rada wydziału. Ponadto w stosunku do Wydziału Teologicznego Sekcja w Tarnowie władzę posiada wielki wicekanclerz ${ }^{18}$.

Prawodawstwo kanoniczne wprowadza do zwierzchnich władz uczelni kościelnych funkcję wielkiego kanclerza: „Wielki kanclerz reprezentuje Stolicę Świętą wobec uniwersytetu lub wydziału i jednocześnie uniwersytet lub wydział wobec Stolicy Świętej”19. Funkcję tę sprawuje zazwyczaj biskup diecezjalny tej diecezji, na której terenie położony jest uniwersytet. W określonych okolicznościach może zostać ustanowiony przez Kongregację Edukacji Katolickiej wielki wicekanclerz ${ }^{20}$. Wielkim kanclerzem UPJPII jest każdorazowy arcybiskup metropolita krakowski. Wielki kanclerz:

troszczy się o dobro i rozwój uniwersytetu, popiera badania naukowe i pracę dydaktyczną uczelni, czuwa nad czystością nauki katolickiej, dobrymi obyczajami i dyscypliną całej wspólnoty uniwersyteckiej, dba o jedność uczelni i jej łączność z Kościołem powszechnym i lokalnym, zabezpiecza środki materialne ${ }^{21}$.

Wielki kanclerz zwraca się do Stolicy Apostolskiej w ważnych sprawach dotyczących uniwersytetu, m.in.: o zatwierdzenie tekstu statutu, o zatwierdzenie wyboru rektora i dziekanów, o nihil obstat przy nominacjach profesorskich i nadawaniu doktoratu honoris causa ${ }^{22}$. Nadaje tytuł profesora i stanowisko profesora nadzwyczajnego i zwyczajnego, podpisuje dyplomy potwierdzające nadanie tytułu naukowego i stopni naukowych, udziela misji kanonicznej pracownikom uniwersytetu wykładającym dyscypliny odnoszące się do nauki wiary i moralności, a w uzasadnionych przypadkach ją odwołuje, sprawuje opiekę nad majątkiem uniwersytetu, w poważnych i nagłych przypadkach, ze względu na dobro studentów i wiernych, może zawiesić w czynnościach nauczyciela akademickiego ${ }^{23}$. Powyższe uprawnienia i zadania wobec Wydziału Teologicznego Sekcja w Tarnowie, w porozumieniu z wielkim kanclerzem, spełnia - mutatis mutandis - wielki wicekanclerz. Jest nim biskup tarnowski ${ }^{24}$.

\footnotetext{
${ }^{18}$ Statut, n. 11.

${ }^{19}$ Jan Paweł II, konst. apost. Sapientia christiana, 12.

${ }^{20}$ Por. tamże, 13-14.

${ }^{21}$ Statut, n. 12, p. 1.

${ }^{22}$ Por. tamże, n. 12 , p. 3, 5, 8, 13 .

${ }^{23}$ Por. tamże, n. 112 , p. $8,14,9,15$; n. 65.

${ }^{24}$ Por. tamże, n. 13
} 


\section{Zadania senatu uniwersyteckiego}

Prawodawstwo kościelne przewiduje powołanie senatu, jak i rektora uniwersytetu:

Władze akademickie obejmują bądź pojedyncze osoby, bądź też kolegia. Wśród pierwszych należy wyliczyć przede wszystkim rektora lub przewodniczącego oraz dziekana. Natomiast władzami o charakterze kolegialnym są różne organy kierujące, czyli rady uniwersytetu lub wydziału ${ }^{25}$.

Zarządzenia do konstytucji Sapientia christiana nazywają radę uniwersytecką senatem akademickim ${ }^{26}$. Tę nazwę przejmuje Statut UPJPII w Krakowie: „Senat jest naczelnym organem kolegialnym władzy Uniwersytetu w sprawach organizacyjnych, naukowych, dydaktycznych, studenckich, administracyjnych i finansowych"27.

Senat, zgodnie ze Statutem Uniwersytetu, prowadzi swoją działalność przez cztery lata. To postanowienie jest odzwierciedleniem aktualnego ustawodawstwa państwowego, które wprowadziło czteroletnią kadencję dla senatów wyższych uczelni. W skład senatu wchodzą osoby spełniające ważne funkcje w uniwersytecie. Są to: rektor, który przewodniczy senatowi, trzech prorektorów, dziekani wszystkich pięciu wydziałów (w tym dziekan Wydziału Teologicznego Sekcja w Tarnowie), dyrektor Instytutu Prawa Kanonicznego oraz kanclerz, którego dla uniknięcia pomyłki z wielkim kanclerzem Statut nazywa także dyrektorem administracyjnym ${ }^{28}$. Można powiedzieć, że wyliczeni członkowie należą do senatu z urzędu, a swoje funkcje otrzymują na podstawie wyborów. Jedynie kanclerz jest powoływany przez rektora po wyrażeniu przez senat zgody, którą wyraża w głosowaniu. Ta liczba członków senatu z urzędu wynosi 11. Pozostali członkowie senatu pochodzą z wyboru rożnych gremiów wchodzących w skład wspólnoty akademickiej uniwersytetu i ją reprezentujących. Każda rada wydziału wybiera spośród siebie jednego samodzielnego pracownika naukowego, który ją reprezentuje w senacie. Do senatu swoich przedstawicieli wybierają wszyscy pomocniczy pracownicy naukowi, w liczbie nie mniejszej niż 10 procent członków senatu pochodzących z urzędu oraz tych, którzy reprezentują rady wydziałów. $Z$ wyboru znajdują się w senacie przedstawiciele pracowników niebędących nauczycielami akademickimi, w liczbie nie większej niż 10 procent członków senatu, pochodzących z urzędu i reprezentujących rady wydziałów. Również z wyboru mają należeć do senatu przedstawiciele samorządów: studentów i doktorantów, przez nie wybierani, w liczbie nie mniejszej niż 20 procent członków

\footnotetext{
${ }^{25}$ Jan Paweł II, konst. apost. Sapientia christiana, 15.

${ }^{26}$ Ordinationes, 12.

${ }^{27}$ Statut, n. 14.

${ }^{28}$ Por. tamże, n. 15.
} 
senatu pochodzących z urzędu, a także reprezentujących rady wydziałów. Wszyscy członkowie senatu pochodzący z wyborów maja mandat w senacie na cztery lata ${ }^{29}$.

Przywołane określenia Statutu „w liczbie nie mniejszej niż 10 procent”, „w liczbie nie większej niż 10 procent”, „w liczbie nie mniejszej niż 20 procent” wymagają sprecyzowania. Wydaje się, że tego powinien dokonać senat. Proponuje się, żeby w następnej wersji Statutu usunąć tę lukę prawną. Do senatu nie należą, ale mogą na zaproszenie rektora w nim uczestniczyć następujące osoby: 1) dyrektorzy instytutów wydziałowych, międzywydziałowych i międzyuczelnianych; 2) dyrektor biblioteki; 3) dyrektor wydawnictwa; 4) kwestor (główny księgowy). Wyżej wymienionym, uczestniczącym w senacie, przysługuje prawo głosu w tych sprawach, które wchodzą w zakres ich działalności ${ }^{30}$. Powstaje pytanie: dlaczego dyrektor Instytutu Prawa Kanonicznego należy do senatu z urzędu, a pozostali dyrektorzy instytutów mogą w nim uczestniczyć tylko na zaproszenie rektora? Wydaje się, że jest to podyktowane tym, iż jedynie Instytut Prawa został erygowany przez Stolicę Apostolską, a jego dyrektor po wyborze musi zostać przez nią zatwierdzony.

Do zadań senatu należy organizowanie i kierowanie działalnością uniwersytetu, w tym: ustalanie ogólnych kierunków tej działalności, uchwalanie jego statutu, który wymaga zatwierdzenia przez Kongregację Edukacji Katolickiej, uchwalanie regulaminów uczelni, zatwierdzanie regulaminów jej jednostek organizacyjnych i organizacji studenckich, tworzenie nowych wydziałów po aprobacie Kongregacji, powoływanie jednostek organizacyjnych niższej rangi oraz ich przekształcanie, znoszenie już istniejących, rozstrzyganie sporów między wydziałami, określanie zasad rekrutacji na studia, ustalanie pensum dydaktycznego dla poszczególnych stanowisk i uchwalanie zasad zatrudnienia pracowników ${ }^{31}$. Senat ma prawo uczestniczenia lub decydowania w niektórych sprawach personalnych, takich jak: wybór rektora i prorektorów, stwierdzanie poprawności wyborów dziekanów i prodziekanów, nadawanie osobom zasłużonym tytułu doktora honoris causa oraz innych odznaczeń i nagród, powoływanie, na wniosek rektora, sekretarza senatu, sekretarza kancelarii rektoratu i rzecznika prasowego uniwersytetu, wyrażanie zgody na powołanie przez rektora kanclerza i kwestora uniwersytetu oraz określanie ich zadań, wyrażanie opinii o kandydatach na dyrektora biblioteki i zatwierdzanie kierowników studiów ${ }^{32}$.

Senat jest kompetentny zatwierdzać niektóre uchwały niższych jednostek organizacyjnych uczelni, zwłaszcza rad wydziałów i rad instytutów. Dotyczy to: zmian norm szczegółowych funkcjonowania wydziałów i instytutów; powoływania dyrektorów, $\mathrm{z}$ wyjątkiem dyrektora IPK; powoływanie na stanowiska profesorskie; powierzanie zajęć dydaktycznych samodzielnym pracownikom naukowym w wymiarze etatu

\footnotetext{
${ }^{29}$ Por. tamże, n. 15.

${ }^{30}$ Por. tamże, n. 18.

${ }^{31}$ Por. tamże, n. 20, p. 1, 2, 5, 7, 9e, 12, 17, 18, 22.

${ }^{32}$ Por. tamże, n. 20, p. 3, 4, 8, 13, 14, 15, 16.
} 
lub jego części; umów o stałej współpracy naukowej, dydaktycznej i wydawniczej uniwersytetów; umów o stałej współpracy naukowej z wyższymi seminariami duchownymi i wyższymi instytutami wiedzy religijnej, które odpowiadają afiliacji według konstytucji Sapientia christiana ${ }^{33}$.

Senat kieruje działalnością majątkowo-finansową uniwersytetu przez to, że: uchwala dla niego plan rzeczowo-finansowy, uwzględniając postulaty rad wydziatów i innych jego jednostek; zatwierdza roczne sprawozdania z wykonania planu; podejmuje uchwały dotyczące: nabywania i zbywania nieruchomości oraz innych składników majątkowych, przyjmowania darowizny, spadku lub zapisu, przystąpienia do spółki lub innej organizacji gospodarczej oraz utworzenia fundacji; uchwalania regulaminów stypendialnych oraz uchwalania zasad podziału dotacji państwowych ${ }^{34}$.

Senat w swojej działalności korzysta z pomocy różnorodnych komisji. Powołuje dwie odrębne komisje dyscyplinarne, z których jedna zajmuje się pracownikami, druga zaś - studentami. Powołuje również dwóch rzeczników dyscyplinarnych. Komisja i rzecznicy działają według regulaminu zatwierdzonego przez senat, który jest dla nich instancją odwoławczą ${ }^{35}$. Zupełnie odmienny charakter posiadają inne komisje senackie, które stanowią dla senatu organy opiniodawcze. Stąd też nie posiadają uprawnień decyzyjnych. Ich strukturę, zadania i działalność określają regulaminy uchwalone przez senat ${ }^{36}$. Są to np. komisja wydawnicza czy komisja prawna.

Senat podejmuje decyzje przez głosowanie. Do ważnego podjęcia decyzji zasadniczo wystarcza większość bezwzględna, zwana inaczej zwykłą (połowa obecnych plus jeden), przy obecności co najmniej połowy członków ${ }^{37}$. Stąd brak połowy członków plus jeden wyklucza możliwość podejmowania decyzji przez senat. W pewnych przypadkach podjęcie ważnej decyzji będzie wymagać większości kwalifikowanej $2 / 3$ głosów obecnych członków senatu. Tak jest przy wyborze rektora i prorektorów oraz w sprawach uznanych przez zwykłą większość senatu za większej wagi ${ }^{38}$.

Głosowanie w senacie może dokonywać się w sposób tajny lub jawny. Tajne głosowanie obowiązuje: 1) przy wyborach władz; 2) przy wnioskach dotyczących zmiany statutu; 3) w sprawach dotyczących stanowisk profesorskich i tytułu doktora honoris causa; 4) we wszystkich innych sprawach personalnych. W pozostałych sprawach głosowanie z reguły jest jawne, chyba że - w poszczególnym przypad$\mathrm{ku}$ - senat większością bezwzględną obecnych poleci przeprowadzenie głosowania tajnego ${ }^{39}$. Uchwały senatu, który jest organem ustawodawczym uniwersytetu, obowiązują rektora, inne organy uczelni oraz wszystkich członków wspólnoty

\footnotetext{
${ }^{33}$ Por. tamże, n. 20, p. 9, 10, 11.

${ }^{34}$ Por. tamże, n. 20, p. 19, 20, 23.

${ }^{35}$ Por. tamże, n. 20, p. 24.

${ }^{36}$ Por. tamże, n. 19.

${ }^{37}$ Por. tamże, n. 21.

${ }^{38}$ Por. tamże, n. 22.

${ }^{39}$ Por. tamże, n. 23.
} 
akademickiej ${ }^{40}$. Podjęta przez senat prawomocna uchwała nie wymaga niczyjego zatwierdzenia, jedynie wielki kanclerz, jeśli uzna taką uchwałę na szkodliwą dla uczelni, może ją zawiesić i polecić senatowi jej ponowne rozważenie ${ }^{41}$.

\section{Kompetencje innych władz uniwersytetu}

Bezpośrednie kierownictwo uniwersytetem sprawuje jego rektor, który reprezentuje uczelnię na zewnątrz i jest przełożonym wszystkich pracowników i studentów. Kieruje współpracą uniwersytetu z instytucjami naukowymi w kraju i za granicą. Troszczy się o przestrzeganie prawa oraz o bezpieczeństwo i porządek na terenie uczelni. Zwołuje posiedzenia senatu i im przewodniczy, pośredniczy między radami wydziałów i senatem a wielkim kanclerzem. Może uczestniczyć w posiedzeniach wszystkich rad wydziałów i instytutów z prawem głosu ${ }^{42}$. Rektora wybiera urzędujący senat spośród samodzielnych pracowników nauki na okres czterech lat, zgodnie z regulaminem wyborczym. Kandydatów mają prawo zgłaszać wszyscy członkowie senatu. W pierwszym i drugim głosowaniu wymagana jest większość kwalifikowana $2 / 3$ głosów obecnych ${ }^{43}$. W kolejnych głosowaniach wystarczy większość bezwzględna głosów obecnych ${ }^{44}$. To postanowienie regulaminu wyborczego nie jest sprzeczne ze statutem i ma zapobiec przeciąganiu się głosowań, a także ich bezskuteczności. Regulamin wyborczy nie przewiduje wcześniejszego (przed zebraniem wyborczym) zgłaszania kandydatów. Wydaje się, że taką ewentualność można by wprowadzić do regulaminu, dając kandydatom okazję zaprezentowania programu oraz lepszego ich poznania przez wyborców. O dokonanym wyborze rektora wielki kanclerz bezzwłocznie zawiadamia Stolicę Apostolską, która jest uprawniona do zatwierdzenia dokonanego wyboru. Obejmując urząd, rektor składa wyznanie wiary ${ }^{45}$.

Rektora zastępują prorektorzy we wszystkich sprawach zwyczajnych dotyczących działania uniwersytetu, według podziału kompetencji ustalonego przez senat. Prorektorów wybiera urzędujący senat spośród samodzielnych pracowników nauki na okres czterech lat. Kandydatów na prorektorów może zaproponować rektor, co jednak nie wyklucza możliwości zgłaszania kandydatów przez innych członków senatu. Kandydatura na prorektora ds. studenckich wymaga zgody większości przedstawicieli samorządu studenckiego w senacie. Głosowanie na każdego prorektora odbywa się oddzielnie, przy czym w pierwszym i drugim głosowaniu wymagana

\footnotetext{
${ }^{40}$ Por. tamże, n. 24.

${ }^{41}$ Por. tamże, n. 25.

${ }^{42}$ Por. tamże, n. 26.

${ }^{43}$ Por. tamże, n. 22; n. 28.

${ }^{44}$ Por. Regulamin wyboru rektora i prorektorów, 29.05.1995, Archiwum UPJPII, nowy regulamin wyboru rektora i prorektorów 17.03.2014 (do poprzedniego regul.)

${ }^{45}$ Por. tamże, n. 28, p. 2.
} 
jest większość kwalifikowana 2/3 głosów obecnych na głosowaniu, w kolejnych wystarczy większość bezwzględna. Rektor i prorektorzy mogą być wybierani tylko na dwie bezpośrednio po sobie następujące kadencje ${ }^{46}$.

W przypadku gdy rektor przestanie pełnić funkcję przed upływem kadencji, senat dokonuje bezzwłocznie wyboru nowego rektora na dokończenie kadencji. Jeśliby jednak wybór nastąpił na okres krótszy niż 6 miesięcy przed ukończeniem kadencji, nowo wybrany rektor sprawuje urząd także przez całą następną kadencję ${ }^{47}$. Przywołaną normę można stosować, per analogiam, także do prorektorów. Omawiany statut przynosi jeszcze nową ważną normę, której nie było w dotychczasowych statutach krakowskiej uczelni teologicznej, mianowicie chodzi o odwołanie rektora lub prorektora. Taki wniosek może zostać zgłoszony przez co najmniej 1/3 członków senatu lub przez wielkiego kanclerza. Uchwałę o odwołaniu podejmuje senat. $\mathrm{Na}$ takim zebraniu wymagana jest obecność co najmniej $2 / 3$ jego członków i potrzebna jest kwalifikowana większość co najmniej 3/4 głosów obecnych za odwołaniem ${ }^{48}$.

Kolejnym organem kolegialnym sprawującym władzę w Uniwersytecie Papieskim jest rada wydziału:

Rada wydziału zajmuje się sprawami dotyczącymi studiów, nauczania i wychowania. Czuwa nad rozwojem badań naukowych i programem studiów, nadzoruje ich realizację oraz działa na rzecz podnoszenia kwalifikacji naukowych i zawodowych pracowników ${ }^{49}$.

Pełnoprawnymi członkami rady wydziału są: dziekan, prodziekani, profesorowie i doktorzy habilitowani zatrudnieni na wydziale w pełnym wymiarze czasu pracy $^{50}$. Do rady wydziału należą także kuratorzy katedr niebędący samodzielnymi pracownikami naukowymi i dwaj przedstawiciele pomocniczych pracowników naukowych przez nich wybrani, ich kompetencje określa statut ${ }^{51}$.

Członkami rady wydziału są również przedstawiciele studentów i doktorantów wydziału $^{52}$. Statut nie określa ich liczby ani sposobu powoływania, jak również ich kompetencji. Jest to luka prawna, która winna być uzupełniona w nowej wersji statutu, który winien być odnowiony po pięciu latach od zatwierdzenia, jak to już wyżej zaznaczyliśmy. Wydaje się, że wystarczy dwóch przedstawicieli studentów i jeden doktorantów, powołanych przez samorząd studencki i samorząd doktorantów, a ich głos dotyczyłby spraw bezpośrednio związanych ze studentami i doktorantami. Do rady wydziału nie należą, ale mogą w jej obradach uczestniczyć, dysponując

\footnotetext{
${ }^{46}$ Por. tamże. n. $27 ; 28 ; 29 ; 30$.

${ }^{47}$ Por. tamże, n. 28, p. 3.

${ }^{48}$ Por. tamże, n. 31.

${ }^{49}$ Por. tamże, n. 32.

${ }^{50}$ Por. tamże, n. 33, p. 1, 2, 3.

${ }^{51}$ Por. tamże, n. 34, p. 4, 5, 7.

${ }^{52}$ Por. tamże, n. 34, p. 6.
} 
tylko głosem doradczym, profesorowie emerytowani. Taki sam głos mają wszyscy pracownicy naukowo-dydaktyczni, uczestniczący w poszerzonych zebraniach rady wydziału, które winny odbywać się raz w semestrze ${ }^{53}$.

Specyfiką rady Wydziału Teologicznego jest uczestniczenie w niej rektorów wyższych seminariów duchownych i dyrektorów instytutów, które zawarły z Wydziałem Teologicznym umowę o współpracy naukowej ${ }^{54}$. Inspiratorem i pomysłodawcą ich zawierania był kard. Karol Wojtyła jako wielki kanclerz Papieskiego Wydziału Teologicznego w Krakowie. Miały one za cel zabezpieczenie podstawowego wykształcenia o charakterze akademickim oraz stosownych do tego wykształcenia stopni akademickich; chodziło głównie o magisteria, które były nadawane absolwentom kończącym podstawowe studia teologiczne. Przywołane umowy są zawierane także aktualnie i nadal owocują stopniami akademickimi ${ }^{55}$.

Do zadań rady wydziału należy troska o rozwój struktury wydziału przez powoływanie katedr i innych jednostek organizacyjnych, wydziałowych, specjalności i specjalizacji, a w razie potrzeby ich znoszenie, zatwierdzanie kierowników specjalizacji wybranych przez pracowników tworzących je katedry, mianowanie kierowników katedr, zakładów, pracowni oraz kierowników studiów przywydziałowych, powoływanie potrzebnych komisji wydziałowych ${ }^{56}$. Rada wydziału troszczy się o awanse naukowe i zawodowe przez: przeprowadzanie przewodów o tytuł naukowy i stanowiska profesora zwyczajnego i nadzwyczajnego, doktora habilitowanego oraz doktora, nadawanie tytułów zawodowych i stopni naukowych, przedkładanie senatowi wniosków o nadanie tytułu doktora honoris causa oraz innych odznaczeń i nagród ${ }^{57}$. Do kompetencji rady wydziału należy: ustalanie ogólnych kierunków jego działalności, ustalanie programów nauczania i planów studiów, określanie zasad rekrutacji na studia, podejmowanie uchwał w innych sprawach określonych w obowiązującym prawie państwowym i kościelnym ${ }^{58}$.

Rada wydziału jest uprawniona do przeprowadzenia wyboru dziekana i prodziekanów. Dziekana wybiera się spośród samodzielnych pracowników nauki na okres czterech lat. Nowy statut wprowadził możliwość wyboru prodziekanów niebędących samodzielnymi pracownikami nauki, wystarczy posiadanie stopnia doktora, są wybierani na cztery lata. Kandydatów na dziekana mają prawo zgłaszać wszyscy wyborcy, zaś w zgłaszaniu kandydatów na prodziekanów pierwszeństwo ma nowo wybrany dziekan. W pierwszym i drugim głosowaniu wymagana jest większość kwalifikowana $2 / 3$ obecnych wyborców, przy czym quorum stanowi bezwzględna

\footnotetext{
${ }^{53}$ Por. tamże, n. 34, p. 8, 9.

${ }^{54}$ Por. tamże, n. 33, p. 8.

${ }^{55}$ Por. J. Dyduch, Papież Jan Pawet II, protektor Papieskiej Akademii Teologicznej, [w:] Sympozjum naukowe z okazji 15-lecia pontyfikatu Jana Pawła II, red. J. Szczurek, R. Zawadzki, Kraków 1994, s. 116.

${ }^{56}$ Por. Statut, n. 34, p. 5, 6, 7, 9, 14.

${ }^{57}$ Por. tamże, n. 34, p. 11, 12, 13.

${ }^{58}$ Por. tamże, n. 34, p. 1, 2, 10, 15.
} 
większość członków rady wydziału, posiadających prawo wyboru, w następnych głosowaniach wystarczy zwykła większość. Wybór dziekana wymaga zatwierdzenia przez Kongregację Edukacji Katolickiej ${ }^{59}$. Jeśli dziekan lub prodziekan przestanie pełnić swoją funkcję przed upływem kadencji, wówczas rada wydziału wybiera nowego dziekana lub prodziekana na pozostały okres kadencji ${ }^{60}$. Rada wydziału może odwołać dziekana lub prodziekana, stosując analogiczną procedurę jak przy odwołaniu rektora czy prorektora - mutatis mutandis - (por. n. 31) ${ }^{61}$.

Zwyczajną radę wydziału zwołuje dziekan raz w miesiącu, a w razie potrzeby zwołuje zebranie nadzwyczajne. Zobowiązany jest także zwołać radę, jeśli przynajmniej połowa jej członków złoży taki wniosek. Zasadniczo rada wydziału podejmuje ważnie uchwały zwykłą większością głosów, przy wymaganym quorum przynajmniej połowy jej członków. Jedynie przy wyborach w pierwszym i drugim głosowaniu wymagana jest większość kwalifikowana 2/3 głosów obecnych, o czym wspominaliśmy wyżej. Również w sprawach większej wagi, uznanych za takie przez radę zwykłą większością, do podjęcia uchwały wymaga się większości kwalifikowanej $2 / 3$ głosów obecnych. Uchwała rady może zostać uchylona przez senat, jeśli tenże uznałby ją za sprzeczną z obowiązującymi przepisami lub dobrem uniwersytetu. Spośród pomocniczych pracowników nauki rada wybiera na cztery lata sekretarza, który sporządza protokoły z jej zebrań ${ }^{62}$.

W kompetencjach rektora w szczególny sposób uczestniczy administracja uniwersytetu, którą kieruje rektor ${ }^{63}$. Jej struktura jest następująca: „Administracja Uniwersytetu Jana Pawła II w Krakowie obejmuje następujące piony i działy: a) kancelarię rektoratu, dziekanaty wydziałów i sekretariaty innych jednostek organizacyjnych; b) kwesturę; c) sprawy personalne; d) archiwum; e) informatyzacje; f) działalność gospodarczą; g) techniczno-administracyjny" ${ }^{64}$. Przywołana struktura administracyjna może zostać zmieniona przez senat. Bezpośrednim przełożonym pracowników administracji uniwersytetu, w zakresie ustalonym przez rektora, jest kanclerz (dyrektor administracyjny). Jego współpracownikiem jest kwestor jako główny księgowy. Kanclerza, sekretarza kancelarii rektoratu i kwestora powołuje rektor za zgodą senatu ${ }^{65}$.

Powołanie i działalność władz Uniwersytetu Papieskiego Jana Pawła II reguluje jego statut, który został sporządzony zgodnie z wytycznymi zawartymi w konstytucji

\footnotetext{
${ }^{59}$ Por. tamże, n. 34, p. 3 ; n. 43.

${ }^{60}$ Por. tamże, n. 44.

${ }^{61}$ Por. tamże, n. 45.

${ }^{62}$ Por. tamże, n. $35-40$.

${ }^{63}$ Por. tamże, n. 98.

${ }^{64}$ Tamże, n. 99.

${ }^{65}$ Por. tamże, n. 100-104.
} 
apostolskiej Sapientia christiana. Władze w Uniwersytecie sprawują zarówno organy kolegialne, jak i osoby fizyczne. Do organów kolegialnych należą: Kongregacja Edukacji Katolickiej, Konferencja Episkopatu Polski, senat, rady wydziałów; do osób fizycznych zaś: wielki kanclerz, wielki wicekanclerz, rektor i dziekani wydziałów.

\section{Summary}

\section{The authorities of the Pontifical University of John Paul II in Cracow}

The Pontifical University of John Paul II in Cracow is an ecclesiastical university. The Apostolic Constitution Sapientia christiana and the statute of the university regulate its governance. The collegial bodies and the natural persons exercise the authority in question. Among the first group one can count: the Congregation for Catholic Education, the Polish Episcopal Conference, the University Senate; while the second category consists of: the Great Chancellor, the vice Great Chancellor, Rector, and deans of faculties.

\section{Keywords}

The Pontifical University of John Paul II in Cracow, ecclesiastical university, rector, statutes, dean 